Volume-V, Issue-02, July-December, 2010

\title{
Compliance Practices in Garment Industries in Dhaka City
}

\author{
MD. ARIFUR RAHMAN ${ }^{1}$ \\ MIR SOHRAB HOSSAIN ${ }^{2}$
}

\begin{abstract}
The readymade garment $R M G$ industry in Bangladesh has experienced an unprecedented growth .over the last three decades and become a fast growing industry in Bangladesh. This industry plays a vital role in the economy in terms of export earnings, employment generation, poverty alleviation and empowering the woman. For development of this sector, Bangladesh needs to emphasize on the factory working environment, social issues, labor relations and compliances with codes of conduct. This paper is based on descriptive and inferential research. The paper suggests the improvement of factory activities through compliances and finds out a close relationship between compliance and productivity.
\end{abstract}

\section{INTRODUCTION}

The readymade garment (RMG) industry of Bangladesh commenced its journey in the late 1970s and within a short period of time emerged as an important player in the economy in terms of export earnings, employment generation, poverty alleviation and empowering of women. Bangladesh exports its RMG products mainly to the United States of America (USA) and the European Union (EU). Garments exports from Bangladesh have been growing at an impressive rate in recent years. In 2007-08 alone, the garment export earned, a record level of US $\$ 10.7$ billion in 2007-08. Moreover, it accounts for over 75 percent of the country's total export earnings, provides employment almost 5 million people, accounts for over 10 percent of the country's GDP, and contributes around $40 \%$ of its manufacturing output.

The prospects of RMG sector, however, in Bangladesh not only depends on availability of cheap labor and government's liberal policy but also depends on compliance with codes of conduct. Compliance means to comply with something or

\footnotetext{
${ }^{1}$ Senior Lecturer in Management, Department of Business Administration, Northern University Bangladesh

${ }^{2}$ Assistant Professor, Business Administration Discipline, Khulna University, Khulna
} 
yield to the wishes of another. RMG sector of Bangladesh needs to improve the factory working environment and various social issues related to the industry. International buyers are very particular about compliance with codes of conduct before placing any import order. Poor housekeeping, storage system, ineffective monitoring and controlling system, disorganized production layout, lack of teambased work, rented factory premises, narrow staircases, closed environment, insufficient light and air, clean drinking water, separate wash room for male and female, etc. are common practices in most of the RMG factories in Bangladesh.

Bangladesh Garment Manufacturers and Exporters Association(BGMEA) and Bangladesh Knitwear Manufacturers and Exporters Association (BKMEA) set standards for compliance like factories must have alternative stairs, basic fire equipment, approved layout plan from concerned authority for ensuring safe building construction, group insurance for workers, hygienic sanitation facility and first aid appliance, as well as ensuring minimum wages and flexible jobs for the workers. There are many recognized compliance bodies worldwide like ILO, ISO 14001, WRAP, BSCI, ETI, SAI, FLA. Owners of RMG factories and government can seek help from those bodies to improve the standard of environment as well as products of theie industries. In this paper, the existing compliance practices of RMG factories in Bangladesh, partcularly factories located in Dhaka city, are examined. This paper also tries to reveal the acceptability of compliance provisions to the employed workers.

\subsection{Objectives of Study}

The objectives of the study are as follows:

i. To provide an overview of the present compliance situation in the garment factories in Dhaka city.

ii. To find out the acceptability of compliance provisions among the existing employee group.

iii. To find out the problems and prospects of compliance in garment industry.

\section{LITERATURE REVIEW}

The Bangladesh Garment Manufacturers and Exporters Association (BGMEA) has formulated its own code of conduct for the industry, in collaboration with the major trade unions, and has set up a compliance unit that monitors labor conditions in its members' factories (UNIFEM 2008). In 2006, the Government passed a new labor code, after 12 years of deliberation and activism. It applies to all workers, and the new sections relevant to the garment industry include written contracts and identity cards, timely payment of wages, revised minimum wage, paid maternity 
leave and explicit laws against sexual harassment. The export-quota system and the availability of cheap labor are the two main reasons behind the success of the industry (Haider 2007). But unfortunately in many RMG factories the labors are often seen being deprived of their rights. According to Amin (2009), Coordinator of the Bangladesh Garment Workers Unity Council (BGWUC), "The garment workers of Bangladesh may be the most deprived labor force in the world. Most are paid between US\$14 and US\$16 per month, the lowest salary in the world." He also added "Only a few factories here maintain international standards, and many of them do not implement any worker health and safety measures." The Financial Express (2008), a daily English newspaper of Bangladesh, referred to a recent study conducted by a local think tank that has revealed that investors in the RMG sector have more than doubled their earnings in the past seven years. Despite this increase, however, it is a remorse that many owners are not paying their laborers regularly and all sorts of extraneous arguments are put forward for non-payment of their salaries. New Age (2009), another prominent daily English newspaper, reported that the majority of garment factories do not yet comply with many wage and workplace standards specified in the tripartite agreement of 2006. At the global level, campaigns have drawn attention to abuses of workers' rights in global supply chains and put pressure on international corporations to take greater responsibility for employees through corporate codes of conduct. Local employers in the Bangladesh garment industry must now demonstrate compliance with these codes to win orders from international buyers (UNIFEM 2008). According to International Labor Organization (2010), buyers make sourcing decisions based on four factors: price, quality, how long it takes to get produce to the marketplace and social compliance, including compliance with labor standards.

In order to export readymade garments, it is not only the quality parameters that are important towards acceptance of the product as per the intended end use, but also the working environment, in which the garments are to be produced, is equally important so that sweatshop concept is totally taken care of and the code of conduct must be stretched towards achieving the objectives of social compliance issues (Das 2008). Research showed that when companies that dealt with foreign buyers adhered to codes of conduct, conditions improved for the workers in the factories stated by (Mahmud) in one of her articles. In some large factories, health and safety standards improved and other benefits were introduced such as timely payment of salaries, proper overtime rates and maternity leave. Haider (2007) in his study stated that the social dimensions of the RMG industry are getting more attention from consumers, social workers, welfare organizations and brand name international buyers. International buyers are very particular about compliance with codes of conduct. Currently, many international buyers demand compliance with their "code 
of conduct" before placing any garment import order. The factory working environment is not very satisfactory. So in order to sustain in the industry, Bangladesh needs to improve the factory working environment and various social issues related to the RMG industry. Informal recruitment, low literacy level, wage discrimination, irregular payment and short contracts of service are very common practices in the RMG factories in Bangladesh. People's Daily Online China (2008) reported that the Bangladeshi caretaker government is to take stern action from August 1 against owners of garment factories who failed to implement compliance issues like providing minimum wage to workers. German Embassy (2010) stated that PROGRESS, a joint project of the Bangladesh Ministry of Commerce and the German Federal Ministry, has consequently turned its full attention to the area of social compliance and assisting the government in the following areas: implementation of the new labor law, media campaigns, training and retraining measures for compliance inspectors, advisors, and the introduction of a new monitoring and evaluation system. According to Hameeda Hossain, Convener of the Shromik Nirapotta Forum, newspaper reports and statements by business leaders suggest that they may now be willing to recognize genuine labor problems which is reflected by the fact that BGMEA and BKMEA are reported to have conceded the need to revise pay scales, issue employment letters, non-enforcement of overtime. The question of safety conditions was also raised.

\section{METHODOLOGY}

Both descriptive and inferential research were conducted to identify different dimensions of compliance of garment industry, such as housekeeping storage, working environment, production layout and controlling system, and management policies and practices in Bangladesh. The focus of the research is the lower level male and female workers of the garment industries located in Dhaka. Both primary and secondary sources were used in this study. Primary data was collected through a structured questionnaire (with a likert type 5 point scale) from 150 operating level employees of 10 garment industry located in Dhaka city. For primary data, interview survey was carefully designed and conducted to evaluate the technical compliance performance of garment industry. Secondary data were collected by consulting official documents of garment industries, internet, industry manuals, audit reports, annual reports, articles, etc. The data were collected during 2009. Statistical Package of the Social Sciences (SPSS Software) was used for analyzing data. 


\section{Hypotheses}

$H_{0}$ : Garment industries in Dhaka city are practicing compliance policies and procedures.

$H_{1}$ : Garment industries in Dhaka city are not practicing compliance policies and procedures.

\section{EMPIRICAL FINDINGS}

This study has tried to measure the extent to which the garment industries are following their compliance obligations or not. Collected data were analyzed and interpreted in line with the objective of this study. From the analysis, the mean and standard deviation of all variables have been calculated separately. Means are indicative of the variables acceptability, on the basis of compliance standard, whereas standard deviations are idicative of deviation among the respondents response.

The respondents were asked about housekeeping storage facilities of the organization. In responses to this question, 40 percent of the respondents strongly agree that their organization has a good housekeeping facility while 21 percent of the respondents are agree about this statement, with a mean of 3.93 which lies in between Agree and Neutral of the scale and standard deviation 1.2. The respondents were asked whether the storage facility is well organized or not. About 67 percent replied that their organizations have a very well organized storage facility, with a mean of 3.93 whice lies in between agree and neutral of the scale the and standard deviation 1.2. From the analysis it is noted that 33.33 percent are strongly agree with the statement that the operations are handled efficiently, whereas 13.33 percent are strongly disagree with this statement, with a mean of 3.53 which lies in between Agree and Neutral position and standard deviation 1.51. Although majority of the respondents $(63.34 \%)$ are either strongly agree or agree that the current compliance systems have improved work posture for greater efficiency, 20 percent respondents

have given negative answer to this question. In this case the mean is 3.8 which lies in between Agree and Neutral position and standard deviation is 1.62.

It is observed from the analysis that out of 150 respondents 60 have given their strong positive answer regarding the improvement of the controlling and monitoring system which has led the organization to minimize mistakes. But a significant number of respondents (20 percent) disagree with this statement. The mean is 3.67 which lies in between Agree and Neutral position and standard deviation is 1.62. 
Regarding flexibility and responsibility of the job,70 percent of the respondents strongly felt that they have responsible and flexible job and a considerable portion of respondents have neutral thinking regarding this issue, which calculated mean is 3.93 and deviation among the respondents response was 1.69. In regard to the question whether the organization removes fatigue to keep employees alert and productive, a majority portion (65\%) opine positively, whereas a sizeable percent of respondents didn't comment regarding this. Here the mean has been calculated as 3.99 which indicates the employees agreeableness proportion while respondents responses deviate from each other up-to 1.73. Workers were asked about how far the production layout is appropriate for their given task. In this regard, most of respondents replied that they are working in a standard production layout though a considerable (30 percent of respondents) contradict with this positive impression of the workers. It indicates that nonetheless employees are satisfied with their production outline; they have, to some extent difficulties for working with the present production design. Respondents were asked how far organization permits and persuade group work. Sixty percent and 30 percent of total respondents respectively give their strong positive opinion and optimistic attitude regarding this matter, whereas 40 percent of respondents disagree with this issue, with the mean value of 3.73 and standard deviation 1.14.

The interview with workers of the surveyed RMG factories reveals that a significant percentage (40 percent) stongly opined that their organizations have production progress control system, while 26.67 percent, 13.33 percent and 13.33 percent are agree,neutral and disagree with this matter. The respondents were asked whether the organization practices diversity management or not. About 67 percent have replied that they have a well practiced diversity management system but a significant portion of the respondents (20 percent) were in neutral position, with a mean value of 3.93 which lies in between Agree and Neutral position and standard deviation 1.2.

From the analysis it is noted that 33.33 percent strongly agree with the statement that the organization provides the equal employment opportunity for all employees and associates irrespective of the employees' race, color, religion, age, sex, creed, national origin, ancestry, marital status, familial status, affection and sexual orientation, disability, and 26.67 percent agree with this but a good number of respondents (13.33 percent) disagree with this statement, with a mean of 3.53 which lies in between Agree and Neutral position and standard deviation 1.51. 
It is the policy of most of the RMG industries to keep workplace free of harassment. Harassment by co-workers, customers, vendors, agents or any other third parties is strictly forbidden. Any associate or worker who believes that he/she has been subjected to harassment, or has seen someone else harassed, must report it immediately to his/her supervisor or the local Human Resources Division. Although majority of the respondents (63.34 percent) are either strongly in agreement or in agreement that the they are not harassed by the top level executives, 20 respondents reported that employees are harrased by the top level executives. The mean is 3.8 which lies in between "Agree" and Neutral position and standard deviation is 1.62. The employers' association of RMG sector of Bangladesh is committed to maintaining a work environment free from violence, threats of violence, intimidation and other disruptive behavior. Employers of this sector are committed to take seriously all reports of such incidents and deal with them promptly and appropriately. Individuals who commit such acts may be removed from the premises and may be subject to disciplinary action. It is observed from the analysis that out of 150 respondents 60 are strongly and 30 are positively expressed that their organization do not permit workplace violence. But a significant number of respondents $(20 \%)$ disagree with this statement. Here the mean is 3.67 which lies in between Agree and Neutral position and standard deviation is 1.62. Respondents were asked whether organization has acceptable use of information technologies. Examination of their answers to this question reveals that 70 percent of respondents strongly believe that they have information dissemination system by using modern information technologies and a considerable portion of respondents have neutral thinking regarding this issue, which calculated mean is 3.93 and deviation among the respondents response is 1.69 .

Figure 1 shows the means and standard deviations of the variables of compliance practice in the surveyed garment industries. In the Figure 1 variables like the organization has a good housekeeping storage, the storage is well organized, the operations are handled efficiently, organization improves work posture for greater efficiency, organization improves monitoring and controlling system to minimize mistakes, organization designs responsible and flexible jobs, organization removes fatigue to keep workers alert and productive, organization's production layout is appropriate, the organization encourages group work, organization has a production progress control system, rganization practices diversity management, organization provides the equal employment opportunity, employees are not harassed by the top level executives, organization doesn't have workplace 
violence, and organization has acceptable use of information technologies denote A, B, C, D,E, F, G, H, I, J, K,L,M,N and O respectively.

Figure 01: Graphical presentation of Means and Standard Deviations of the Statements

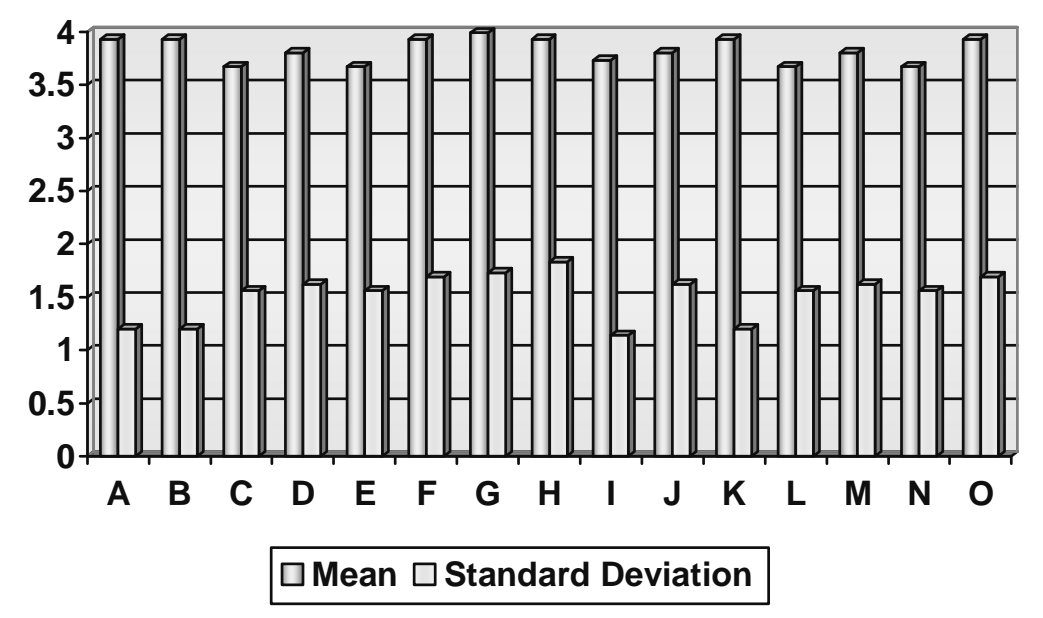

\section{Testing of Hypotheses}

The 99\% acceptance zone (confidence level) confirms two equal areas of 0.495 each. From the Normal Distribution table it can be found that the appropriate Z value for $1 \%$ significance level is 2.58 . Now the limits of the acceptance zone can be determined as:

Standard Error $=\sigma_{-}^{-}=\frac{\sigma}{\sqrt{n}}=\frac{S}{\sqrt{n}}=\frac{0.1197}{\sqrt{15}}=0.0309$

Now standardizing the sample mean, $\mathrm{Z}=\frac{\bar{X}-\mu_{\overline{-}}}{\sigma_{\bar{x}}}$

$$
\begin{aligned}
\therefore \mu_{\bar{x}}+2.58 \sigma_{\bar{x}} & =3.83+2.58 \times 0.0309 \\
& =3.83+0.10062 \\
& =3.930 \text { (Upper limit) } \\
\mu_{\bar{x}}-2.58 \sigma_{\bar{x}} & =3.83-2.58 \times 0.0309 \\
& =3.83-0.10002=3.729 \text { (Lower limit) }
\end{aligned}
$$


$\therefore \mu_{\bar{x}}=\frac{57.38}{n-1}=3.83$

$$
\begin{aligned}
\therefore \text { Sample Standard Deviation }(S) & =\frac{\sqrt{\sum\left(\bar{X}-\mu_{x}\right)^{2}}}{n-1} \\
& =\sqrt{\frac{0.2007}{0.1197}} \\
& =0.1197 \text { (See table } 06 \text { in the appendix) }
\end{aligned}
$$

From the analysis it is revealed that the means of ten statements lie within the acceptance zone and five fall outside the acceptance zone. So, it can be concluded that the null hypothesis is accepted. However, factors that are fallen inside the rejected zone should be given much more concentration. They are as follows:

1. The operations are handled efficiently

2. Organization improves monitoring and controlling system to minimize mistakes

3. Organization removes fatigue to keep workers alert and productive

4. Organization provides the equal employment opportunity

5. Organization does not have workplace violence.

\section{CONCLUSIONS AND RECOMMENDATIONS}

The international textile business is tremendously competitive. In the context of growing competition among RMG exporting countries and consumer preference for products that meet internationally recognized standards, it is essential for Bangladesh's RMG suppliers to improve compliance in their factories. RMG authorities in Bangladesh should implement effective policies on housekeeping, material storage and handling, work station design, fair wage, fair disciplinary action, and workplace violence. RMG is, however, the most flourishing sector in Bangladesh and it would be imperative that each and every issue related to improvement of productivity as well as quality is strictly followed to survive in the global market. Owners of RMG factories must emphasize on employment conditions, working conditions and occupational safety and health management to be more competitive in the international trade of textile and clothing business era. Moreover, regular practice of compliance codes of conduct can bring higher price of products, lower labor unrest, less worker turnover rate, highest worker morality, 
highest productivity and product quality, smooth industrial relation as well as global image and reputation. So, Bangladesh RMG firms need to deal with above mentioned compliance issues strictly in order to remain competitive in the global market.

\section{Recommendations}

1. RMG factories should ensure proper production and official layout with perfect place materials, tools. Organization should tape up unused machine and keep it away from the manufacturing plant safely.

2. All of the employees related with this potential industry should be enthusiastic to avoid the conflict of interests. This means that employees and employers should not place themselves in situation that might face them to choose between their own interest, business or financial interest and the interests of readymade garment industries.

3. Workers should be properly seated for waist and foot rest. Workforce is the heart of anyorganization. RMG factories should guarantee the workforce's proper rest for the fix time which can easily be helpful for the productivity of this industry.

4. Industries should provide chair with backrest. Fatigue will surely arise during work in a place; to remove such type of tiredness garment factories should make available place with suitable chair which can ensure backrest of the workforce in the right time.

5. RMG industries should have adequate leg space to allow easy leg movement of the workers. That means layout of the manufacturing plant should be more spacious.

6. To be competitive, industries should comply with international standard code, such as ISO or imported countries standard code.

7. Factories should have effective fire distinguisher and separate and adequate space for entrance and exit of the workers. Every displays and control systems should be clear to all employees and workers.

8. RMG industries should ensure health, safety and standard work environment for the employees. In this case, organizations should provide proper ventilation, sufficient light and air. For organizing such facilitiesm owners should comply at a minimum with legal standards, minimize the use and discharge of hazardous substances and promote recycling of resources. 


\section{REFERENCES}

Bangladesh Garment Manufacturers and Exporters Association (BGMEA). 2010. Main Functions of BGMEA (2010). Available from: http: //www. bgmea.com.bd/home/pages/aboutus. Accessed June 14, 2010.

Bangladesh Knitwear Manufactures and Exporters Association (BKMEA). 2010. Social Compliance: Ongoing Initiatives of BKMEA (2010). Available from: http://www.bkmea.com/social_compliance.php. Accessed June 14, 2010.

Das, Subrata. 2008. "Social Compliance Issue in the Apparel Sector of Bangladesh." Official web site of Fiber 2 Fashion.

Haider, Mohammed Ziaul. 2007. "Competitiveness of the Bangladesh Ready-made Garment Industry in Major International Markets." Asia-Pacific Trade and Investment Review Vol. 3, No. 1, June .

Hossain, Hameeda. 2007. "Compliance The Garment Crisis: Who Done It?" Bangladesh Garments Industry.

Islam, Sinful. 2005. "In Bangladesh, garment workers' payday not a sure thing" Brainstorming An Investigative View.

International Labor Organization. 2010. "International Trade Agreements and the Cambodian Garment Industry: How Has the Multi-Fiber Agreement Affected Cambodia?"

Khan, Shahiduzzaman. 2007. "Challenges Facing the Garments Industry." The Financial Express. January 27.

German Embassy Dhaka. 2010. "Social and Environmental Standards in the Bangladesh Ready-Made Garment Sector" Available from: www.dhaka.diplo.de/.../Bekleidungsindustrie__Seite.html. Accessed June 15, 2010.

People's Daily Online. June 03, 2008. "Bangladesh Implementing Minimum Wage in Garment Industry." China.

The Daily New Age. April 19, 2009. "Garment industry still flouting minimum compliance. 2009." Editorial.

United Nations Development Fund for Women (UNIFEM). 2008. "Women Seeking Accountability in the Bangladeshi Garment Industry." Available from: www.unifem.org/progress/2008/.../POWW08. Accessed June 15, 2010. 


\section{APPENDIX}

\section{Demographical Analysis of Respondents}

From this analysis, respondents' gender, age, designation and monthly income are shown in tabular form. These are given below one by one:

TABLE 1

\section{GENDER OF RESPONDENTS}

\begin{tabular}{l|c|c|c}
\hline Type of Respondents & Frequency & Percent & Cumulative Percent \\
\hline Male & 115 & 76.7 & 76.7 \\
Female & 35 & 23.3 & 100.0 \\
Total & 150 & 100.0 & \\
\hline
\end{tabular}

Source: Field Survey - 2009

TABLE 2

AGE OF RESPONDENTS

\begin{tabular}{c|c|c|c}
\hline Age & Frequency & Percent & Cumulative Percent \\
\hline $21-25$ & 15 & 10.0 & 10.0 \\
$26-30$ & 40 & 26.7 & 36.7 \\
$31-35$ & 35 & 23.3 & 60.0 \\
$36-40$ & 35 & 23.3 & 83.3 \\
$41-45$ & 20 & 13.3 & 96.7 \\
$51-55$ & 05 & 3.3 & 100.0 \\
Total & 150 & 100.0 & \\
\hline
\end{tabular}

Source: Field Survey - 2009

TABLE-03

MONTHLY INCOME OF RESPONDENTS

\begin{tabular}{l|c|c|c|c}
\hline Monthly Income & Frequency & Percent & Valid Percent & Cumulative Percent \\
\hline Below Tk. 10,000 & 105 & 70.0 & 70.0 & 70.0 \\
Tk. 10,000 - Tk. 30,000 & 40 & 26.7 & 26.7 & 96.7 \\
Tk. 30,000 - Tk. 50,000 & 05 & 3.3 & 3.3 & 100.0 \\
Total & 150 & 100.0 & 100.0 & \\
\hline
\end{tabular}

Source: Field Survey - 2009 
TABLE 4 DESIGNATION OF RESPONDENTS

\begin{tabular}{lccccc}
\hline Designation & Frequency & Percent & Valid Percent & Cumulative Percent \\
\hline Accountant & 05 & 3.3 & 3.3 & 3.3 \\
Assistant Cutting Master & 05 & 3.3 & 3.3 & 6.7 \\
Assistant Store & 05 & 3.3 & 3.3 & 10.0 \\
Cutting In charge & 05 & 3.3 & 3.3 & 13.3 \\
Director & 05 & 3.3 & 3.3 & 16.7 \\
Factory Manager & 05 & 3.3 & 3.3 & 20.0 \\
Finishing In charge & 05 & 3.3 & 3.3 & 23.3 \\
Line Chief & 15 & 10.0 & 10.0 & 33.3 \\
Line Supervisor & 30 & 20.0 & 20.0 & 53.3 \\
Maintenance In charge & 05 & 3.3 & 3.3 & 56.7 \\
Manager (Finance and & 05 & 3.3 & 3.3 & 60.0 \\
Accounting) & 05 & 3.3 & 3.3 & 63.3 \\
Manager (Merchandizing) & 05 & 3.3 & 3.3 & 66.7 \\
Manager (Production) & 05 & 3.3 & 3.3 & 70.0 \\
Managing Director & 05 & 3.3 & 3.3 & 73.3 \\
Merchandiser & 05 & 3.3 & 3.3 & 76.7 \\
Pattern Master & 05 & 3.3 & 3.3 & 80.0 \\
Quality Control In charge & 05 & 13.3 & 13.3 & 93.3 \\
Quality Controller & 3.3 & 3.3 & 96.7 \\
Store In charge & 3.3 & 3.3 & 100.0 \\
Trimming Man & 05 & 100.0 & 100.0 & \\
Total & 05 & & & \\
\hline
\end{tabular}

Source: Field Survey - 2009 
TABLE - 5

\section{CALCULATION OF MEAN AND STANDARD} DEVIATION OF EACH FACTOR

\begin{tabular}{|c|c|c|c|c|}
\hline Title of the Statement & $\mathrm{N}=150$ & Percentage & Mean & $\begin{array}{c}\text { Standard } \\
\text { Deviation }\end{array}$ \\
\hline \multicolumn{5}{|c|}{ A. The organization has a good housekeeping storage } \\
\hline Strongly Agree & 60 & 40 & -- & -- \\
\hline Agree & 40 & 26.66 & 3.93 & 1.2 \\
\hline Neutral & 30 & 20 & -- & -- \\
\hline Disagree & 20 & 13.33 & -- & -- \\
\hline Strongly Disagree & 0 & 0 & -- & -- \\
\hline \multicolumn{5}{|l|}{ B. The storage is well organized } \\
\hline Strongly Agree & 50 & 33.33 & -- & -- \\
\hline Agree & 50 & 33.33 & 3.93 & 1.2 \\
\hline Neutral & 40 & 26.67 & -- & -- \\
\hline Disagree & 10 & 6.67 & -- & -- \\
\hline Strongly Disagree & 0 & 0 & -- & -- \\
\hline \multicolumn{5}{|c|}{ C. The operations are handled efficiently } \\
\hline Strongly Agree & 50 & 33.33 & -- & -- \\
\hline Agree & 40 & 26.67 & -- & -- \\
\hline Neutral & 30 & 20 & 3.67 & 1.56 \\
\hline Disagree & 20 & 13.33 & -- & -- \\
\hline Strongly Disagree & 10 & 6.67 & -- & -- \\
\hline \multicolumn{5}{|c|}{ D. Organization improves work posture for greater efficiency } \\
\hline Strongly Agree & 55 & 36.67 & -- & -- \\
\hline Agree & 40 & 26.67 & 3.8 & 1.62 \\
\hline Neutral & 35 & 23.33 & -- & -- \\
\hline Disagree & 10 & 6.67 & -- & -- \\
\hline Strongly Disagree & 10 & 6.67 & -- & -- \\
\hline \multicolumn{5}{|c|}{ E. Organization improves monitoring and controlling system to minimize mistakes } \\
\hline Strongly Agree & 60 & 40 & -- & -- \\
\hline Agree & 30 & 20 & -- & -- \\
\hline Neutral & 20 & 13.33 & 3.67 & 1.56 \\
\hline Disagree & 30 & 20 & -- & -- \\
\hline Strongly Disagree & 10 & 6.67 & -- & -- \\
\hline \multicolumn{5}{|c|}{ F. Organization designs responsible and flexible jobs } \\
\hline Strongly Agree & 70 & 46.66 & -- & -- \\
\hline Agree & 30 & 20 & 3.93 & 1.69 \\
\hline Neutral & 30 & 20 & -- & -- \\
\hline Disagree & 10 & 6.67 & -- & -- \\
\hline
\end{tabular}




\begin{tabular}{|c|c|c|c|c|}
\hline Strongly Disagree & 10 & 6.67 & -- & -- \\
\hline \multicolumn{5}{|c|}{ Cont. Table 5} \\
\hline Title of the Statement & $\mathrm{N}=150$ & Percentage & Mean & $\begin{array}{c}\text { Standard } \\
\text { Deviation }\end{array}$ \\
\hline \multicolumn{5}{|c|}{ G. Organization removes fatigue to keep workers alert and productive } \\
\hline Strongly Agree & 40 & 26.67 & -- & -- \\
\hline Agree & 65 & 43.33 & 3.99 & 1.73 \\
\hline Neutral & 35 & 23.33 & -- & -- \\
\hline Disagree & 8 & 5.33 & -- & -- \\
\hline Strongly Disagree & 2 & 1.33 & -- & -- \\
\hline \multicolumn{5}{|c|}{ H. Organization's production layout is appropriate } \\
\hline Strongly Agree & 80 & 53.33 & - & -- \\
\hline Agree & 30 & 20 & 3.93 & 1.83 \\
\hline Neutral & 0 & 0 & -- & -- \\
\hline Disagree & 30 & 20 & -- & -- \\
\hline Strongly Disagree & 10 & 6.67 & -- & -- \\
\hline \multicolumn{5}{|c|}{ I. The organization encourages group work } \\
\hline Strongly Agree & 60 & 40 & -- & -- \\
\hline Agree & 30 & 20 & -- & -- \\
\hline Neutral & 20 & 13.33 & 3.73 & 1.14 \\
\hline Disagree & 40 & 26.67 & -- & -- \\
\hline Strongly Disagree & 0 & 0 & -- & -- \\
\hline \multicolumn{5}{|c|}{ J. Organization has a production progress control system } \\
\hline Strongly Agree & 60 & 40 & -- & -- \\
\hline Agree & 40 & 26.67 & 3.8 & 1.62 \\
\hline Neutral & 20 & 13.33 & -- & -- \\
\hline Disagree & 20 & 13.33 & -- & -- \\
\hline Strongly Disagree & 10 & 6.67 & -- & -- \\
\hline \multicolumn{5}{|c|}{ K. Organization practices diversity managemetn } \\
\hline Strongly Agree & 50 & 33.33 & -- & -- \\
\hline Agree & 50 & 33.33 & 3.93 & 1.2 \\
\hline Neutral & 40 & 26.67 & -- & -- \\
\hline Disagree & 10 & 6.67 & -- & -- \\
\hline Strongly Disagree & 0 & 0 & -- & -- \\
\hline \multicolumn{5}{|c|}{ L. Organization provides the equal employment opportunity } \\
\hline Strongly Agree & 50 & 33.33 & -- & -- \\
\hline Agree & 40 & 26.67 & -- & -- \\
\hline
\end{tabular}




\begin{tabular}{|c|c|c|c|c|}
\hline Neutral & 30 & 20 & 3.67 & 1.56 \\
\hline Disagree & 20 & 13.33 & -- & -- \\
\hline Strongly Disagree & 10 & 6.67 & -- & -- \\
\hline \multicolumn{5}{|c|}{ Cont. Table 5} \\
\hline Title of the Statement & $\mathrm{N}=150$ & Percentage & Mean & $\begin{array}{r}\text { Standard } \\
\text { Deviation }\end{array}$ \\
\hline \multicolumn{5}{|c|}{ M. Employees are not harassed by the top level executives } \\
\hline Strongly Agree & 55 & 36 & -- & -- \\
\hline Agree & 40 & 27 & -- & -- \\
\hline Neutral & 35 & 23 & 3.8 & 1.62 \\
\hline Disagree & 10 & 6.67 & -- & -- \\
\hline Strongly Disagree & 10 & 6.67 & -- & -- \\
\hline \multicolumn{5}{|c|}{ N. Organization doesn't have workplace violence } \\
\hline Strongly Agree & 60 & 40 & -- & -- \\
\hline Agree & 30 & 20 & -- & -- \\
\hline Neutral & 20 & 13 & 3.67 & 1.56 \\
\hline Disagree & 30 & 20 & -- & -- \\
\hline Strongly Disagree & 10 & 6.67 & -- & -- \\
\hline \multicolumn{5}{|c|}{ O. Organization has acceptable use of information technologies } \\
\hline Strongly Agree & 70 & 47 & & \\
\hline Agree & 30 & 20 & 3.93 & 1.69 \\
\hline Neutral & 30 & 20 & -- & -- \\
\hline Disagree & 10 & 6.67 & -- & -- \\
\hline Strongly Disagree & 10 & 6.67 & -- & -- \\
\hline
\end{tabular}


TABLE 6

CALCULATION OF STANDARD DEVIATIONS

\begin{tabular}{|c|c|c|c|c|c|}
\hline $\begin{array}{c}\text { Sl. } \\
\text { No. }\end{array}$ & Statements & $\begin{array}{l}\text { Mean of } \\
\text { each } \\
\text { statement } \\
(\bar{X})\end{array}$ & $\begin{array}{c}\text { Mean of } \\
\text { means of all } \\
\text { statements } \\
\left(\mu_{-}\right)\end{array}$ & $\begin{array}{l}\text { Deviation } \\
\left(\bar{X}-\mu_{-}\right)\end{array}$ & $\begin{array}{l}\text { Deviation } \\
\text { squared } \\
\left(\bar{X}-\mu_{x}^{-}\right)^{2}\end{array}$ \\
\hline 1. & $\begin{array}{l}\text { The organization has a good } \\
\text { housekeeping storage }\end{array}$ & 3.93 & 3.83 & 0.10 & 0.01 \\
\hline 2. & The storage is well organized & 3.93 & 3.83 & 0.10 & 0.01 \\
\hline 3. & $\begin{array}{l}\text { The operations are handled } \\
\text { efficiently }\end{array}$ & 3.67 & 3.83 & -0.16 & 0.0256 \\
\hline 4. & $\begin{array}{l}\text { Organization improves work } \\
\text { posture for greater efficiency }\end{array}$ & 3.80 & 3.83 & -0.03 & 0.0009 \\
\hline 5. & $\begin{array}{l}\text { Organization improves } \\
\text { monitoring and controlling } \\
\text { system to minimize mistakes }\end{array}$ & 3.67 & 3.83 & -0.16 & 0.0256 \\
\hline 6. & $\begin{array}{l}\text { Organization designs } \\
\text { responsible and flexible jobs }\end{array}$ & 3.93 & 3.83 & 0.10 & 0.01 \\
\hline 7. & $\begin{array}{l}\text { Organization removes fatigue } \\
\text { to keep workers alert and } \\
\text { productive }\end{array}$ & 3.99 & 3.83 & 0.16 & 0.0256 \\
\hline 8. & $\begin{array}{l}\text { Organization's production } \\
\text { layout is appropriate }\end{array}$ & 3.93 & 3.83 & 0.10 & 0.01 \\
\hline 9. & $\begin{array}{l}\text { The organization encourages } \\
\text { group work }\end{array}$ & 3.73 & 3.83 & -0.10 & 0.01 \\
\hline 10. & $\begin{array}{l}\text { Organization has a production } \\
\text { progress control system }\end{array}$ & 3.80 & 3.83 & -0.03 & 0.0009 \\
\hline 11. & $\begin{array}{l}\text { Organization practices } \\
\text { diversity management }\end{array}$ & 3.93 & 3.83 & 0.10 & 0.01 \\
\hline 12. & $\begin{array}{l}\text { Organization provides the } \\
\text { equal employment opportunity }\end{array}$ & 3.67 & 3.83 & -0.16 & 0.0256 \\
\hline 13. & $\begin{array}{l}\text { Employees are not harassed by } \\
\text { the top level executives }\end{array}$ & 3.80 & 3.83 & -0.03 & 0.0009 \\
\hline 14. & $\begin{array}{l}\text { Organization doesn't have } \\
\text { workplace violence }\end{array}$ & 3.67 & 3.83 & -0.16 & 0.0256 \\
\hline 15. & $\begin{array}{l}\text { Organization has acceptable } \\
\text { use of information } \\
\text { technologies }\end{array}$ & 3.93 & 3.83 & 0.10 & 0.01 \\
\hline
\end{tabular}

